\title{
Variasi Morfometrik, Hubungan Panjang Bobot dan Faktor Kondisi Ikan Famili Holocentridae yang Didaratkan di Pelabuhan Perikanan Samudra (PPS) Lampulo, Banda Aceh
}

\author{
Ilham Zulfahmi ${ }^{*}$, Dwi Yuliandhani², Arif Sardi ${ }^{3}$, Neri Kautsari ${ }^{4}$, Yusrizal Akmal ${ }^{5}$ \\ IProgram Studi Pemanfaatan Sumberdaya Perikanan, Fakultas Kelautan dan Perikanan, \\ Universitas Syiah Kuala \\ Jl. Teuku Nyak Arief No.441, Kopelma Darussalam, Kota Banda Aceh, Aceh 23111 Indonesia \\ 2Pusat Kajian dan Konservasi Akuatik, Universitas Islam Negeri Ar-Raniry \\ 3 Program Studi Biologi, Fakultas Sains dan Teknologi, Universitas Islam Negeri Ar-Raniry \\ Lorong Ibnu Sina No.2, Kopelma, Darussalam, Banda Aceh, 23111 Indonesia \\ 4Program Studi Manajemen Sumberdaya Perairan, Fakultas Peternakan dan Perikanan, \\ Universitas Samawa \\ Jl. Bypass Sering, Kerato, Unter Iwes, Sumbawa, Nusa Tenggara Barat, 84316 Indonesia \\ ${ }_{5}^{5}$ Program Studi Akuakultur, Fakultas Pertanian, Universitas Almuslim \\ J. Almuslim, Matang Glumpang Dua, Peusangan, Bireuen, Aceh, 24261 Indonesia \\ Email: ilham.zulfahmi@unsyiah.ac.id
}

\section{Abstract \\ Morphometric Variations, Length-Weight Relationship and Condition Factor of Holocentridae Family Landed at Lampulo Ocean Fishing Port, Banda Aceh}

Understanding of morphometric variation, length-weight relationship, and condition factors needed to support fishery resources management and conservation. Therefore, this study aimed to determine the morphometric variation, length-weight relationship, and condition factors of the Holocentridae family landed at the Lampulo Ocean Fishing Port, Banda Aceh. A total of 50 each of the four species of fish (Myripristis berndty, Myripristis murdjan, Sargocentron tieroides and Sargocentron caudimacullatum) were collected during April 2020. Fish samples were obtained from the catch of fishermen who landed at the Lampulo Ocean Fishing Port, Banda Aceh. The parameters analyzed included morphometric variations (12 characters), length and weight frequency distribution, lengthweight relationship and condition factors. The results showed that the genus Myripristis had more distinguishing characters than the genus Sargocentron, namely $50.00 \%$ and $16.66 \%$, respectively. Myripristis berndty and Myripristis murdjan have 5 distinguishing characters (SL, HL, CPL, HD, PFL and VFL), while Sargocentron tieroides and Sargocentron caudimacullatum only have 2 distinguishing characters (SnL and PFL). The Myripristis genus that were collected tended to more length and heavier compared to the genus Sargocentron. The four spesies of Holocentridae studied had a negative allometric growth pattern $(b<3)$ with condition factor values ranging from 0.787 to 1.417 .

Keywords : Myripristis, Sargocentron, Length distribution, Negative allometric, Coral reef

\begin{abstract}
Abstrak
Pemahaman terkait variasi morfometrik, hubungan panjang bobot dan faktor kondisi sangat diperlukan dalam rangka pengelolaan dan konservasi sumberdaya perikanan. Oleh karenanya, penelitian ini bertujuan untuk mengetahui variasi morfometrik, hubungan panjang bobot serta faktor kondisi dari ikan Famili Holocentridae yang didaratkan di Pelabuhan Perikanan Samudera (PPS) Lampulo, Banda Aceh. Sebanyak masing-masing 50 ekor dari empat jenis ikan (Myripristis berndty, Myripristis murdjan, Sargocentron tieroides dan Sargocentron caudimacullatum) dikoleksi selama bulan April 2020. Sampel ikan diperoleh dari hasil tangkapan nelayan yang didaratkan di Pelabuhan Perikanan Samudera (PPS) Lampulo, Banda Aceh. Parameter yang analisis meliputi variasi
\end{abstract}


morfometrik (12 karakter), selang kelas, hubungan panjang bobot dan faktor kondisi. Hasil penelitian menunjukkan bahwa genus Myripristis memiliki karakter pembeda yang lebih banyak dibandingkan dengan genus Sargocentron yaitu masing masing sebesar $50.00 \%$ dan $16.66 \%$. Myripristis berndty dan Myripristis murdjan memiliki 5 karakter pembeda (SL,HL, CPL, HD, PFL dan VFL), sedangkan Sargocentron tieroides dan Sargocentron caudimacullatum hanya memiliki 2 karakter pembeda ( $\mathrm{SnL}$ dan PFL). Genus Myripristis yang dikoleksi cenderung memiliki ukuran panjang total dan bobot total yang lebih rendah dibandingkan dengan genus Sargocentron. Keempat jenis yang diteliti dalam penelitian ini memiliki pola pertumbuhan alometrik negatif $(b<3)$ dengan nilai faktor kondisi berkisar antara 0.787 hingga 1.417

Kata kunci : Myripristis, Sargocentron, Selang kelas, Allometrik negative, Terumbu karang

\section{PENDAHULUAN}

Ikan dari famili Holocentridae terbagi kedalam delapan genus yaitu Holocentrus, Neoniphon, Sargocentron, Corniger, Myripsristis, Ostichthys, Plectripops dan Pristilepis (Froese, 2012). Genus Neoniphon terdiri dari enam jenis, genus Myripristis terdiri dari 37 jenis, genus Sargocentron terdiri dari 33 jenis, genus Ostichthys terdiri dari 26 jenis, genus Holocentrus terdiri dari lima jenis, genus Plectripops dan Plectripops masing masing terdiri dari dua jenis, sedangkan genus Corniger hanya terdiri dari satu jenis (Froese dan Pauly, 2016). Mayoritas ikan ini terdistribusi di kawasan terumbu karang mulai kedalaman $3 \mathrm{~m}$ hinggal60 m (Nair dan Dineshkumar, 2016).

Hasil penelitian mengungkapkan bahwa dari delapan genus ikan famili Holocentridae, dua genus diantaranya ditemukan di perairan Aceh yaitu genus Myripristis dan Sargocentron (Rudi et al., 2012, Edrus et al., 2013). Jenis ikan dari genus Myripristis yang ditemukan meliputi Myripristis adusta, Myripristis berndti, Myripristis botche, Myripristis melenosticta, Myripristis murdjan, Myripristis hexagona, Myripristis vittata, Myripristis chyseres, Myripristis trachyacron, Myripristis pralinia, dan Myripristis woodsi (Rudi et al., 2012). Sementara itu, dari genus Sargocentron meliputi Sargocentron tieroides, Sargocentron caudimaculatum, Sargocentron sp, Sargocentron cornotum, Sargocentron diadema, Sargocentron rubrum, Sargocentron spiniferum, Sargocentron tiere, Sargocentron punctatissimum, dan Sargocentron ittodai (Edrus et al., 2013; Rudi et al., 2012).
Pelabuhan Perikanan Samudera (PPS) Lampulo merupakan tempat pendaratan ikan terbesar di kota Banda Aceh. Hasil observasi awal menunjukkan bahwa terdapat empat jenis ikan famili Holocentridae yang didaratkan di pelabuhan ini yaitu Myripritis berndti, Myripristis murdjan, Sargocentron tieroides dan Sargocentron caudimaculatum. Bagi nelayan setempat, ikan dari jenis ini dikenal dengan nama Serindang. Ketersediaan ikan ini cenderung mudah diperoleh setiap harinya (tidak tergantung musim). Disamping itu, ikan-ikan ini juga memiliki nilai ekonomis yang baik, berkisar Rp.30.000-35.000/Kg.

Hingga saat ini, penelitian terkait ikan famili Holocentridae di Indonesia masih terbatas pada inventarisasi dan struktur komunitas (Edrus et al., 2013; Bakhtiar et al., 2012; Putri dan Sulaiman, 2016). Informasi terkait variasi morfometrik, hubungan panjang-bobot dan faktor kondisi ikan dari famili ini masih belum diungkap. Kajian morfometrik diperlukan dalam rangka membuktikan posisi ikan jenis-jenis tertentu dalam taksonomi, mengevaluasi perbedaan morfologi antar populasi serta menduga hubungan fiogeniknya (García-Dávila et al., 2005, Streissl dan Hodl, 2002, Haryono, 2001). Sementara itu, kajian hubungan panjang bobot dan faktor kondisi bermanfaat untuk memperkirakan tingkat pertumbuhan, struktur usia dan dinamika populasi ikan sehingga dapat digunakan sebagai dasar dalam pengelolaan perikanan (Ramses, 2020, Rypel dan Richter, 2008). Penelitian ini bertujuan untuk mendeskripsikan variasi morfometrik, hubungan panjang bobot serta faktor kondisi empat jenis ikan dari famili Holocentridae yang didaratkan di PPS Lampulo Banda Aceh. 


\section{MATERI DAN METODE}

Penelitian dilakukan selama bulan April 2020. Pengambilan contoh ikan dilakukan di PPS Lampulo Kuta Alam, Kota Banda Aceh (5,56062'11'"LU dan 95०33'55,21'"BT), sedangkan pengukuran morfometrik dan analisis data dilakukan di Laboratorium Ekologi, Program Studi Biologi, Fakultas Sains dan Teknologi Universitas Islam Negeri ArRaniry, Banda Aceh.

Jumlah contoh ikan yang dikoleksi untuk masing masing jenis yang diteliti (Myripristis berndty, Myripristis murdjan, Sargocentron tieroides, dan Sargocentron caudimacullatum) sebanyak 50 ekor (Gambar 1). Contoh ikan berasal dari hasil tangkapan nelayan yang didaratkan di PPS Lampulo. Contoh ikan selanjutnya dimasukkan ke dalam coolbox dan dibawa ke Laboratorium Prodi Biologi Fakultas Sains dan Teknologi UIN Ar-Ranirry untuk dipreparasi lebih lanjut. Setiap contoh ikan diletakkan di atas nampan dan difoto dalam keadaan segar dengan kepala menghadap kekiri (Sukmono et al., 2013; Maghfiriadi et al., 2019). Pengukuran panjang dilakukan menggunakan caliper digital (Mitutoyo CD-6CS; dengan ketelitian 0,01 $\mathrm{mm})$, sedangkan pengukuran bobot dilakukan dengan menggunakan timbangan digital (Toledo AB-204; dengan ketelitian 0,01 g). Jumlah karakter morfometrik ikan yang diukur adalah sebanyak 12 karakter. Deskripsi dan notasi setiap karakter yang diukur disajikan pada Gambar 2 dan Tabel 1. Data hasil pengukuran kemudian ditransformasikan dengan menggunakan persamaaan Schindler dan Schmidt (2006). Distirubusi tiap jenis ikan dipilah berdasarkan selang kelas

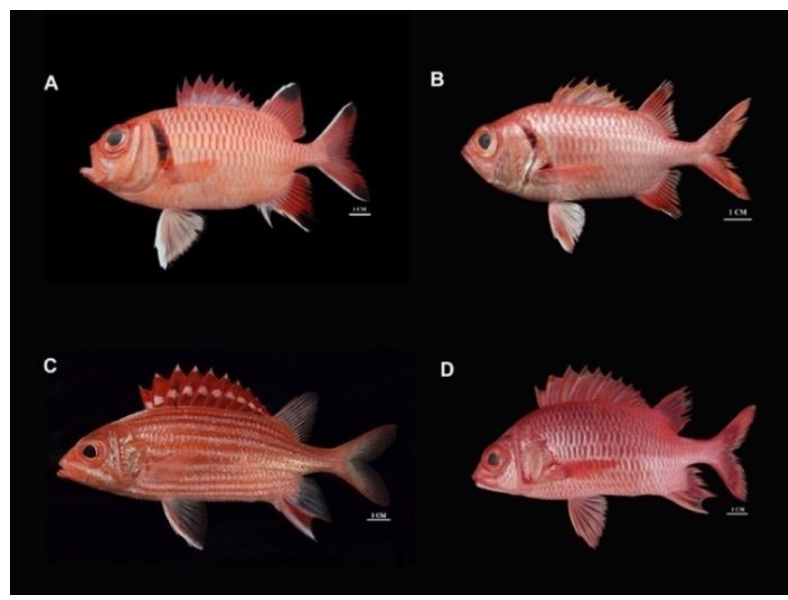

Gambar 1. Morfologi ikan A: Myripritis berndti, B : Myripritis murdjan, C: Sargocentron tieroides, D: Sargocentron cudimacullatum. Skala Bar $1 \mathrm{~cm}$.

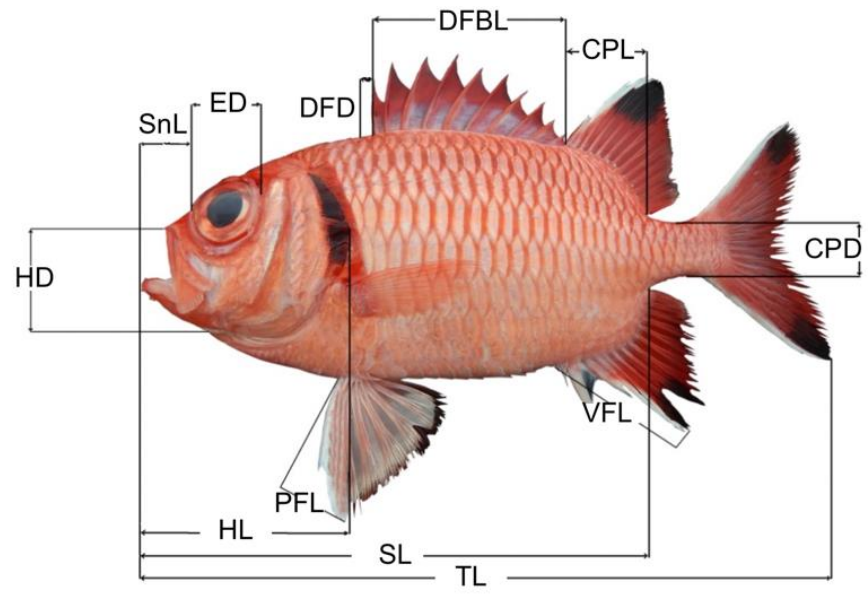

Gambar 2. Karakter Morfometrik yang diukur dalam penelitian ini. 
Tabel 1. Notasi, Nama dan Urairan Karakter Morfometrik Ikan yang Diukur

\begin{tabular}{|c|c|c|c|}
\hline No & Notasi & Nama Karakter & Keterangan \\
\hline 1 & $\mathrm{TL}$ & Panjang Total & $\begin{array}{l}\text { Jarak garis lurus antara ujung kepala yang terdepan } \\
\text { dengan ujung sirip ekor yang paling belakang }\end{array}$ \\
\hline 2 & SL & Panjang Standar & $\begin{array}{l}\text { Jarak garis lurus dari ujung kepala terdepan sampai ke } \\
\text { dasar sirip ekor }\end{array}$ \\
\hline 3 & $\mathrm{HL}$ & Panjang Kepala & $\begin{array}{l}\text { Jarak ujung kepala yang terdepan sampai bagian } \\
\text { yang terbelakang kecelah tutup insang }\end{array}$ \\
\hline 4 & CPL & Panjang Batang Ekor & $\begin{array}{l}\text { Jarak antara ujung sirip punggung sampai kebatang } \\
\text { pangkal ekor }\end{array}$ \\
\hline 5 & SnL & oncong & Jarak antara ujung moncong dengan pangkal mata \\
\hline 6 & DFD & Tinggi Sirip Punggung & $\begin{array}{l}\text { Jarak tertinggi antara ujung sirip dorsal dengan } \\
\text { dasarsirip dorsal }\end{array}$ \\
\hline 7 & DFBL & $\begin{array}{l}\text { Panjang Dasar Sirip } \\
\text { Punggung }\end{array}$ & $\begin{array}{l}\text { Jarak antara ujung sirip punggung depan dengan } \\
\text { ujung sirip punggung belakang }\end{array}$ \\
\hline 8 & ED & Diameter Mata & $\begin{array}{l}\text { Panjang garis tengah bola mata setengah tinggi dari } \\
\text { rongga mata }\end{array}$ \\
\hline 9 & CPD & Tinggi Batang Ekor & $\begin{array}{l}\text { Jarak garis lurus yang diukur vertikal pada bagian } \\
\text { badan yang tertinggi }\end{array}$ \\
\hline 10 & PFL & Panjang Sirip Dada & $\begin{array}{l}\text { Jarak garis lurus yang diukur dari pangkal dasar sirip } \\
\text { dada sampai keujungnya }\end{array}$ \\
\hline 11 & VFL & Panjang Sirip Perut & $\begin{array}{l}\text { Jarak garis lurus antara awal dasar sirip perut sampai } \\
\text { akhir dasar sirip perut }\end{array}$ \\
\hline 12 & $H D$ & Tinggi Kepala & $\begin{array}{l}\text { Jarak garis lurus yang diukur vertikal pada bagian } \\
\text { kepala yang tertinggi }\end{array}$ \\
\hline
\end{tabular}

panjang dan bobot mengacu pada rumus Walpole (1995). Hubungan panjang bobot tiap jenis ikan ikan ditentukan dengan menggunakan rumus De-Robertis dan William (2008). Faktor kondisi diukur dengan menggunakan rumus dari persamaan Effendie (1979).

\section{HASIL DAN PEMBAHASAN}

Kajian morfometrik ikan memiliki beberapa tujuan diantaranya mengevaluasi perbedaan morfologi antar jenis dan populasi (García-Dávila et al., 2005; Streissl dan Hodl, 2002), mengidentifikasi, menganalisis pola pertumbuhan dan kebiasaan makan ikan (Effendie, 2002, Violle et al., 2014). Hasil penelitian menunjukkan bahwa genus Myripristis yang diteliti dalam penelitian ini memiliki karakter pembeda yang lebih banyak dibandingkan dengan genus Sargocentron yaitu masing masing sebesar $50.00 \%$ dan $16.66 \%$ (Tabel 2 dan Tabel 3). Myripristis berndty dan Myripristis murdjan memiliki lima karakter pembeda (SL,HL, CPL, $H D$, PFL dan VFL), sedangkan Sargocentron tieroides dan Sargocentron caudimacullatum hanya memiliki dua karakter pembeda (SnL dan PFL). Jika dibandingkan antar jenis dalam genus yang berbeda, Myripristis berndty dan Sargocentron tieroides cenderung memiliki karakteristik morfometrik yang lebih identik dibanding jenis lainnya (Tabel 2 dan Tabel 3). Analisis fungsi diskriminan ikut menunjukkan bahwa genus Sargocentron memiliki kesamaan morfometrik yang lebih tinggi dibandingkan genus Myripristis berndty (Gambar 3). Menurut Fadhil et al. (2016), variasi morfometrik yang terjadi antar jenis ikan dipengaruhi oleh faktor genetik dan lingkungan. Ikan-ikan yang memiliki kekerabatan genetik tinggi dan habitat yangsama umumnya memiliki kemiripan morfometrik yang lebih tinggi dari pada ikan yang tidak memiliki kekerabatan genetik serta habitat yang berbeda.

Dari 11 parameter morfometrik yang diamati, genus Myripristis cenderung memiliki nilai rasio CPL dan HD yang lebih besar dibandingkan dengan genus Sargocentron. Sebaliknya, genus Sargocentron memiliki nilai rasio $S n L, D F D, D F B L, C P D$ dan PFL yang lebih besar. Peningkatan rasio panjang pada 
bagian caudales ikan karang, diduga berkaitan dengan peran mekanik dalam mendukung gerak dan akselerasi ikan (Jawad, 2015). Sementara itu, peningkatan rasio panjang pada bagian kepala tampaknya terkait dengan jenis makanan dan tingkah laku makan ikan (RodríguezMendoza et al., 2011). Hasil penelitian Edrus dan Suharti (2016), mengungkapkan bahwa genus Myripristis dan Sargocentron memiliki habitat berupa daerah terumbu karang, terutama area celah-celah batuan karang atau sela karang yang bercabang. Ikan-ikan dari genus ini umumnya bersifat nokturnal dalam hal kebiasaan makan (Allen et al., 2003). Hal ini kemudian sering dikaitkan dengan ukuran mata besar yang dimiliki oleh famili Holocentridae (Nair dan Dineshkumar, 2016).
Adanya perbedaan terhadap kebiasaan makan dari kedua genus ikan yang diteliti diduga ikut mempengaruhi nilai rasio panjang moncong (SnL). Genus Sargocentron cenderung memiliki moncong yang lebih panjang dibandingkan genus Myripristis. Hal ini akan mempengaruhi bukaan mulut ikan. Bukaan mulut menjadi salah satu faktor yang mempengaruhi kebiasaan makan ikan. Lebar bukaan mulut menentukan ukuran makanan yang dapat dimakan oleh ikan (Krismono, 2008). Muliati et al. (2017) menyatakan bahwa bertambahnya ukuran tubuh ikan maka selera akan jenis makanan pada ikan juga berubah. Perubahan makanan ikan selalu dipengaruhi faktor selera ikan akan ketersediaan makanan juga dipengaruhi oleh lebar bukaan mulut, bentuk mulut dan ukuran mulut.

Tabel 2. Komparasi 12 parameter morfometrik antar Myripristis berndty, Myripristis murdjan, Sargocentron tieroides, dan Sargocentron caudimacullatum

\begin{tabular}{|c|c|c|c|c|c|}
\hline No. & Parameter & $\begin{array}{c}\text { Myripristis } \\
\text { berndty (A) }\end{array}$ & $\begin{array}{l}\text { Myripristis } \\
\text { murdjan (B) }\end{array}$ & $\begin{array}{l}\text { Sargocentron } \\
\text { tieroides (C) }\end{array}$ & $\begin{array}{c}\text { Sargocentron } \\
\text { caudimacullatum (D) }\end{array}$ \\
\hline 1 & $\mathrm{SL}$ & $65.03 \pm 7.02^{a}$ & $72.65 \pm 67.00^{b}$ & $67.50 \pm 4.28 c$ & $67.49 \pm 4.88^{c}$ \\
\hline 2 & $\mathrm{HL}$ & $25.36 \pm 2.10^{a}$ & $22.70 \pm 2.52^{b}$ & $26.56 \pm 5.99 c$ & $27.16 \pm 2.70^{c}$ \\
\hline 3 & CPL & $9.87 \pm 2.21^{a}$ & $10.83 \pm 1.69 b$ & $9.74 \pm 1.89 a c$ & $9.28 \pm 1.88 a c$ \\
\hline 4 & SnL & $4.96 \pm 1.43 a$ & $4.11 \pm 4.16^{a b}$ & $5.72 \pm 3.94 c$ & $7.26 \pm 1.60^{c}$ \\
\hline 5 & DFD & $5.77 \pm 1.48 a$ & $5.34 \pm 1.52^{b}$ & $6.85 \pm 1.61 \mathrm{ab}$ & $6.87 \pm 1.69 \mathrm{ac}$ \\
\hline 6 & DFBL & $24.11 \pm 4.03^{a}$ & $24.54 \pm 1.69 a$ & $31.98 \pm 8.03^{b}$ & $32.40 \pm 2.79 b c$ \\
\hline 7 & ED & $9.06 \pm 1.55^{a}$ & $8.51 \pm 1.28 a$ & $8.80 \pm 1.87 a$ & $8.44 \pm 1.93 a$ \\
\hline 8 & CPD & $7.48 \pm 2.31 \mathrm{a}$ & $7.42 \pm 6.14^{a}$ & $8.52 \pm 2.11^{a}$ & $9.29 \pm 1.62 \mathrm{ab}$ \\
\hline 9 & PFL & $15.58 \pm 2.06 a$ & $14.19 \pm 1.29 a$ & $17.04 \pm 3.06 a$ & $18.14 \pm 2.56 a$ \\
\hline 10 & VFL & $20.08 \pm 2.51^{a}$ & $18.74 \pm 2.15^{a}$ & $20.47 \pm 2.97 a$ & $20.66 \pm 2.96 a$ \\
\hline 11 & $H D$ & $12.70 \pm 1.81 a$ & $11.36 \pm 2.54 b$ & $10.07 \pm 2.01 c$ & $10.25 \pm 1.12^{\mathrm{cd}}$ \\
\hline
\end{tabular}

Tabel 3. Perbedaan karakter antar Myripristis berndty, Myripristis murdjan, Sargocentron tieroides dan Sargocentron caudimacullatum

\begin{tabular}{|c|c|c|c|}
\hline Perbandingan & $\begin{array}{l}\text { Karakter } \\
\text { Pembeda }\end{array}$ & $\begin{array}{c}\text { Perbedaan } \\
\text { (\%) }\end{array}$ & Parameter \\
\hline $\begin{array}{l}\text { M. berndty vs } \\
\text { M. murdjan }\end{array}$ & 6 dari 12 & $50.00 \%$ & $\mathrm{HL}, \mathrm{SL}, \mathrm{CPL}, \mathrm{HD}, \mathrm{PFL}, \mathrm{VFL}$ \\
\hline $\begin{array}{l}\text { M. berndty vs } \\
\text { S. tieroides }\end{array}$ & 4 dari 12 & $33.33 \%$ & DFBL, HD,DFD, PFL, \\
\hline $\begin{array}{l}\text { M. berndty vs } \\
\text { S. caudimacullatum }\end{array}$ & 7 dari 12 & $58.33 \%$ & $\mathrm{HL}, \mathrm{SnL}, \mathrm{DFBL}, \mathrm{CPD}, \mathrm{HD}, \mathrm{DFD}, \mathrm{PFL}$ \\
\hline $\begin{array}{l}\text { M. murdjan vs } \\
\text { S. tieroides }\end{array}$ & 8 dari 12 & $66.66 \%$ & $\mathrm{HL}, \mathrm{CPL}, \mathrm{SnL}, \mathrm{DFBL}, \mathrm{HD}, \mathrm{VFL}, \mathrm{DFD}, \mathrm{PFL}$ \\
\hline $\begin{array}{l}\text { M. murdjan vs } \\
\text { S. caudimacullatum }\end{array}$ & 9 dari 12 & $75.00 \%$ & $\begin{array}{l}\mathrm{HL}, \mathrm{CPL}, \mathrm{SnL}, \mathrm{DFD}, \mathrm{DFBL}, \mathrm{CPD} \\
\mathrm{HD}, \mathrm{PFL}, \mathrm{VFL}\end{array}$ \\
\hline $\begin{array}{l}\text { S. tieroides vs } \\
\text { S. caudimacullatum }\end{array}$ & 2 dari 12 & $16.66 \%$ & SnL,PFL \\
\hline
\end{tabular}


Selang kelas panjang total ikan Myripristis berndty berkisar antara 140.17 $230.15 \mathrm{~mm}$. Frekuensi panjang total ikan Myripristis berndty tertinggi berada rentang 177.99-192.99 mm yaitu sebanyak 17 ekor, sedangkan frekuensi panjang total terendah berada rentang 225.99-240.99 $\mathrm{mm}$ yaitu sebanyak 2 ekor. Panjang total ikan Myripristis murdjan berkisar antara $130.98-230.50 \mathrm{~mm}$. Frekuensi panjang total tertinggi dari jenis ini berada pada rentang 145,99-160.99 mm yaitu sebanyak 24 ekor. Panjang total ikan Sargocentron tieroides yang dikoleksi berkisar antara $130.99-202.25 \mathrm{~mm}$. Frekuensi panjang total tertinggi ikan Sargocentron tieroides berada pada rentang 161.99 - 176.99 mm yaitu sebanyak 18 ekor, sedangkan frekuensi panjang total terendah berada pada rentang 130.98-145.98 mm yaitu sebanyak 2 ekor. Panjang total ikan Sargocentron caudimacullatum yang dikoleksi berkisar antara $150.42-272.04 \mathrm{~mm}$. Frekuensi panjang total tertinggi dari jenis ini berada pada rentang 177.99-192.99 mm yaitu sebanyak 21 ekor, sedangkan frekuensi panjang total terendahnya berada pada rentang 257.99$272.99 \mathrm{~mm}$ yaitu sebanyak 1 ekor (Gambar 4).
Selang kelas bobot total ikan Myripristis berndty berkisar antara 48.32-247 g. Frekuensi bobot total ikan Myripsristis berndty tertinggi berada rentang 84.22-104.22 g yaitu sebanyak 16 ekor sedangkan frekuensi bobot total terendah brada rentang 184.27-204.27, 204.28224.28 dan 244.30-264.30 g yaitu masingmasing sebanyak 1 ekor. Bobot total ikan Myripristis murdjan berkisar rentang 44.20$225.73 \mathrm{~g}$. Frekuensi bobot total tertinggi jenis ini berada pada rentang 64.21-84.21 g yaitu sebanyak 24 ekor, sedangkan frekuensi bobot total terendah berada pada 204.28-224.28 dan 224.29-244.29 g yaitu masing-masing sebanyak 1 ekor. Bobot total ikan Sargocentron tieroides yang dikoleksi berkisar antara 44.22$152.59 \mathrm{~g}$. Frekuensi bobot total ikan tertinggi ikan Sargocentron tieroides berada pada rentang 84.22-104.22 g yaitu sebanyak 16 ekor, sedangkan frekuensi bobot total ikan terendah berada pada rentang 144,25-164.25 9 yaitu sebanyak 1 ekor. Bobot total ikan Sargocentrum caudimacullatum yang dikoleksi berkisar antara 67.43-202.49 g. Frekuensi bobot total tertinggi dari jenis ini berada pada rentang 84.22-104.22 g yaitu sebanyak 14 ekor, sedangkan frekuensi bobot

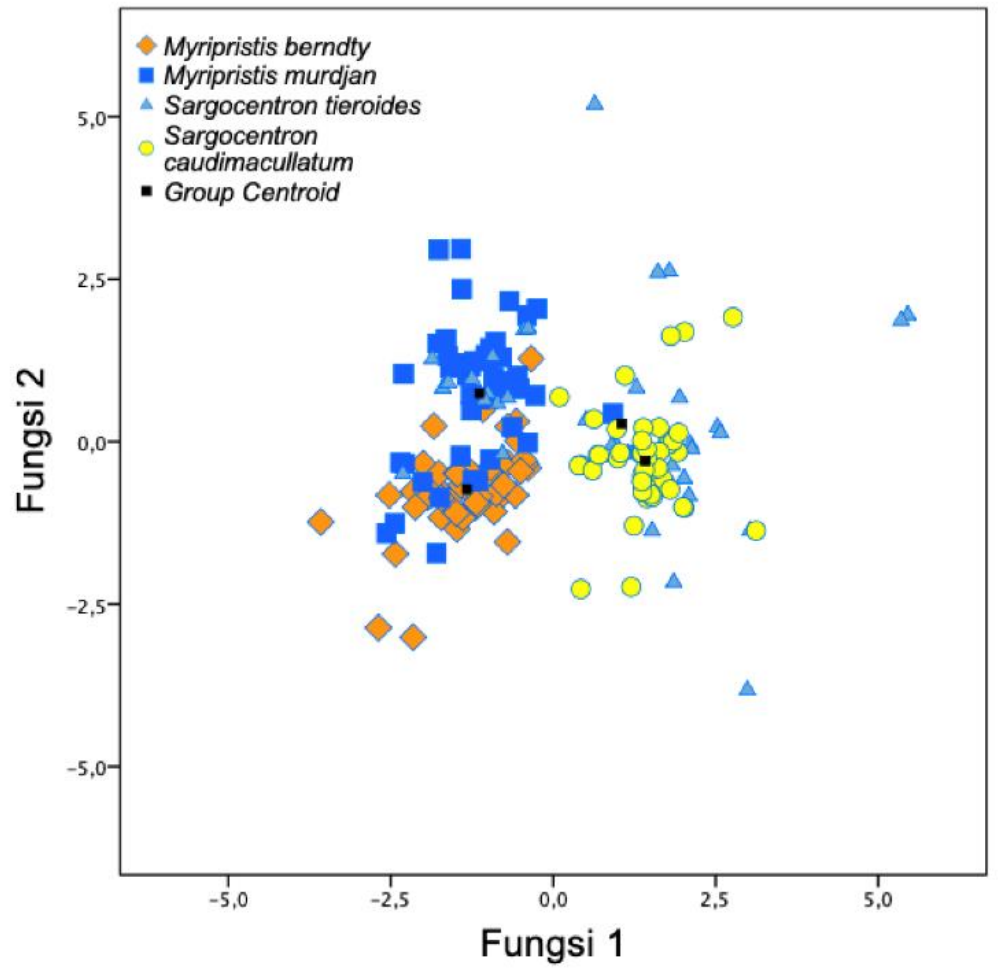

Gambar 3. Analisis fungsi diskriminan antar Myripristis berndty, Myripristis murdjan, Sargocentron tieroides dan Sargocentron caudimacullatum. 


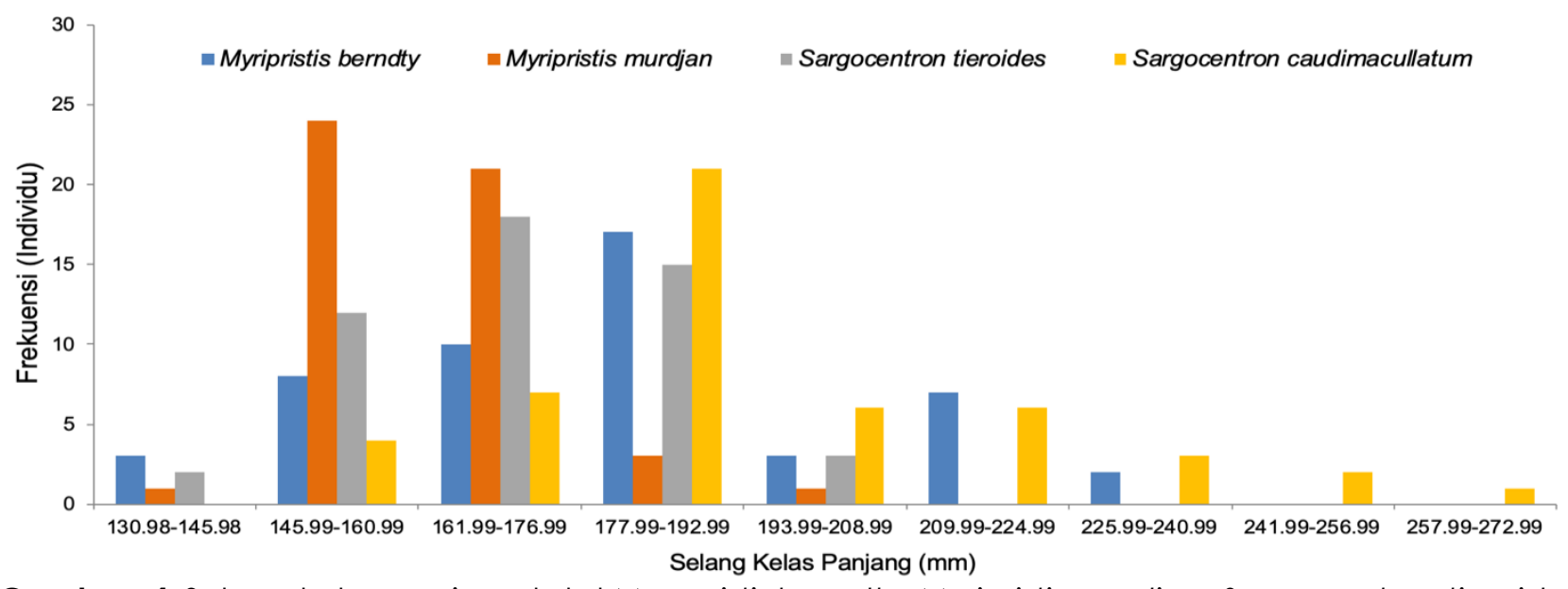

Gambar 4. Selang kelas panjang total Myrypristis berndty, Myripristis murdjan, Sargocentron tieroides dan Sargocentron caudimacullatum.

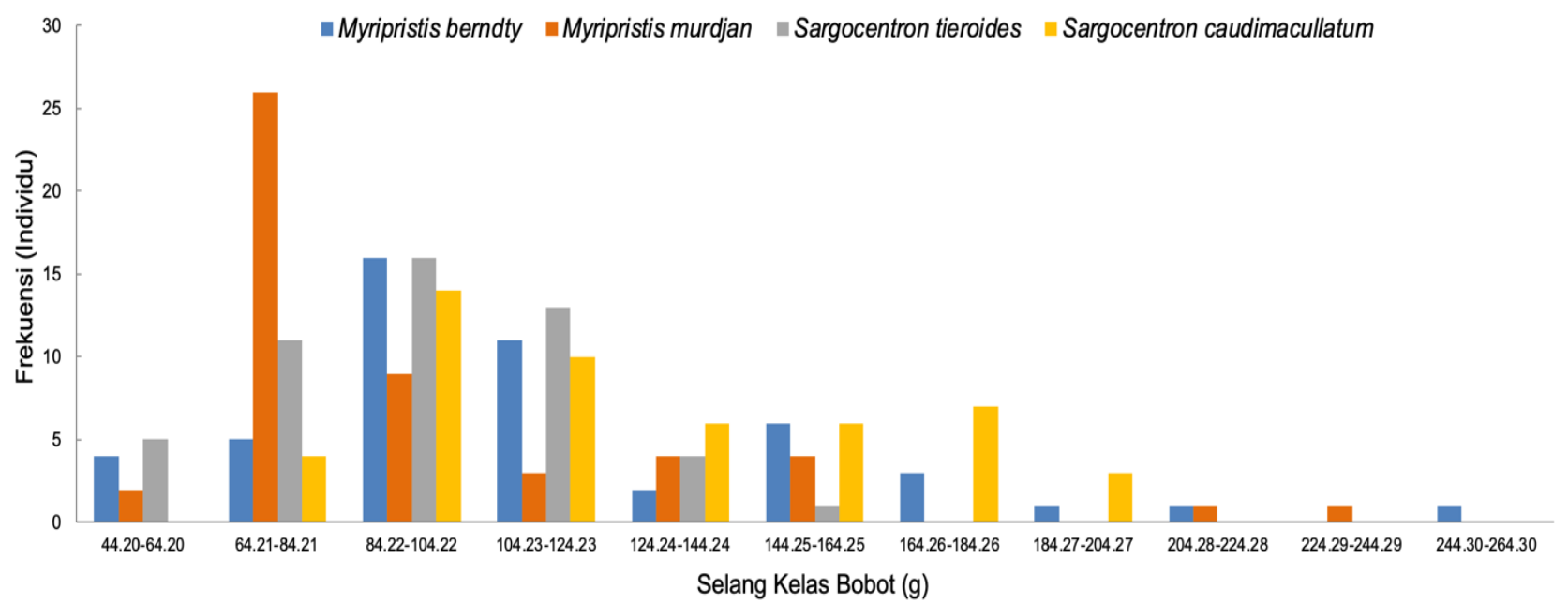

Gambar 5. Selang kelas bobot total Myripristis berndty, Myripristis murdjan, Sargocentron tieroides dan Sargocentron caudimacullatum.

total terendahnya berada pada rentang 184.27-204.27 g yaitu sebanyak 1 ekor (Gambar 5).

Sebagian besar genus Myripristis yang dikoleksi cenderung memiliki ukuran panjang total dan bobot total yang lebih rendah dibandingkan dengan genus Sargocentron. Panjang total tertinggi dari dua jenis Sargocentron yang ditemukan pada penelitian ini tidak berbeda jauh dibandingkan kisaran panjang total ikan dari genus Sargocentron lainnya. Hasil penelitian Artüz dan Golani (2018) menunjukkan bahwa panjang total Sargocentron rubrum berkisar antara 176.60-199.00 mm. Menurut Hedianto et al. (2012) sebaran ukuran ikan dari satu populasi dapat dipengaruhi oleh beberapa faktor yaitu faktor genetik, ketersediaan makanan, pencemaran lingkungan, kompetisi dan predasi. Disamping itu, sebaran ukuran ikan hasil tangkapan juga dipengaruhi oleh jenis alat tangkap yang digunakan. Genus Myripristis dan Sargocentron cenderung memiliki habitat dan kebiasaan makan yang sama. Oleh karenanya, persaingan untuk mendapatkan makanan sangat mungkin terjadi baik antar genus, antar jenis maupun antar populasi. Secara morfologi dan morfometrik genus Sargocentron memiliki sirip (terutama sirip dorsal) yang lebih berkembang dibanding dengan dengan genus Myripristis. Hal ini diduga berpengaruh terhadap kemampuan ikan genus Sargocentron untuk memperoleh makanan dibandingkan dengan ikan genus Myripristis. 
Disamping itu, pada ukuran tertentu, kedua genus ikan ini diduga cenderung mengelompok, sedangkan pada ukuran yang lebih besar, cenderung bersifat soliter (Sumadhiharga et al., 2006). Berdasarkan observasi dan wawancara, terdapat dua jenis alat tangkap yang digunakan untuk menangkap ikan jenis ini yaitu pancing dan jaring insang. Penggunaan alat tangkap yang berbeda juga dapat mempengaruhi ukuran ikan yang dikoleksi dalam penelitian ini. Berdasarkan hasil observasi dan wawancara diketahui bahwa baik genus Myripristis dan genus Sargocentron berukuran kecil umumnya ditangkap menggunakan jaring insang sedangkan yang berukuran besar ditangkap menggunakan pancing. Hal ini selanjutnya memengaruhi sebaran kelas panjang dan bobot ikan. Penelitian khusus dalam bidang genetik pada ikan famili Holocentridae di perairan Indonesia masih belum dilaporkan.

Data panjang-berat dan faktor kondisi merupakan data penting dalam penelitian ikan yang dapat digunakan untuk menduga beberapa faktor diantaranya tingkat pertumbuhan, umur ikan dan dinamika populasi ikan (Morato et al., 2001). Keempat jenis ikan yang diteliti dalam penelitian ini memiliki pola pertumbuhan alometrik negatif $(b<3)$. Nilai koefesien determinasi $\left(R^{2}\right)$ pada Myripristis berndty, Myripristis murdjan, Sargocentron tieroidess dan Sargocentron caudimacullatum masing-masing sebesar $0.825,0.853,0.545$ dan 0.483 (Tabel 4). Myripristis murdjan memiliki nilai koefesien $b$ yang lebih tinggi dibandingkan Myripristis berndty, Sargocentron tieroidess dan Sargocentron caudimacullatum yaitu masing - masing $2.815,2.609,2.028$, dan 1.586 (Tabel 4 dan Gambar 6). Nilai faktor kondisis tertinggi teramati pada Myripristis berndty, diikuti Myripristis murdjan, Sargocentron tieroidess dan Sargocentron caudimacullatum yaitu masing masing sebesar 1.417, 0.099, 1.094 dan 0.787 (Gambar 7)

Pola pertumbuhan allometrik negatif yang diperoleh dalam penelitian ini identik dengan ikan dari genus yang dikoleksi dari perairan Thailand (nilai $b=2.65$ ), dan New Caledonia (nilai $b=2.29$ ) (Letourneur et al., 1998). Walaupun demikian, berbeda dengan kawasan perairan Turki yang memiliki pola pertumbuhan alometrik positif $(b=3,015)$ (Taskavak dan Bilecenoglu, 2001), Teluk Iskenderun (nilai $b=3.098$ ) (Kabakli dan Erguden, 2018), perairan Meditarian (nilai $b=$ 3.091) (Özvaraol dan Tatlıses, 2017) dan

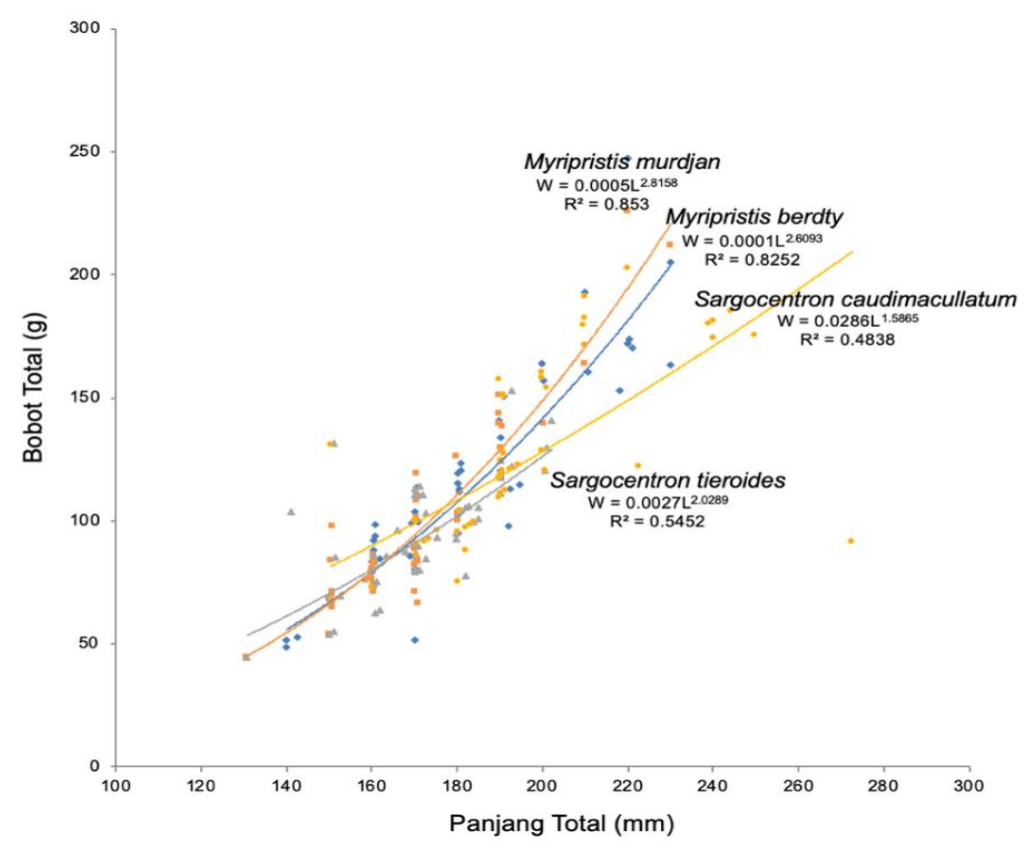

Gambar 6. Hubungan panjang total bobot total Myripristis berndty, Myripristis murdjan, Sargocentron tieroides dan Sargocentron caudimacullatum 
Tabel 4. Hubungan panjang dan bobot total, faktor kondisi dan pola pertumbuhan

\begin{tabular}{lcccccl}
\hline Jenis spesies & $\mathrm{n}$ & $\mathrm{a}$ & $\mathrm{B}$ & $\mathrm{CL}-\mathrm{b}$ (95\%) & $\mathrm{R}^{2}$ & Pola pertumbuhan \\
\hline M.berndty & 50 & 0.0001 & 2.6094 & $2.260-2.957$ & 0.825 & Alometrik negatif \\
M.murdjan & 50 & 0.0005 & 2.8158 & $2.476-3.155$ & 0.853 & Alometrik negatif \\
S.tieroides & 50 & 0.0027 & 2.0289 & $1.491-2.566$ & 0.545 & Alometrik negatif \\
S.caudimacullatum & 50 & 0.0286 & 1.5865 & $1.110-2.062$ & 0.483 & Alometrik negatif \\
\hline
\end{tabular}

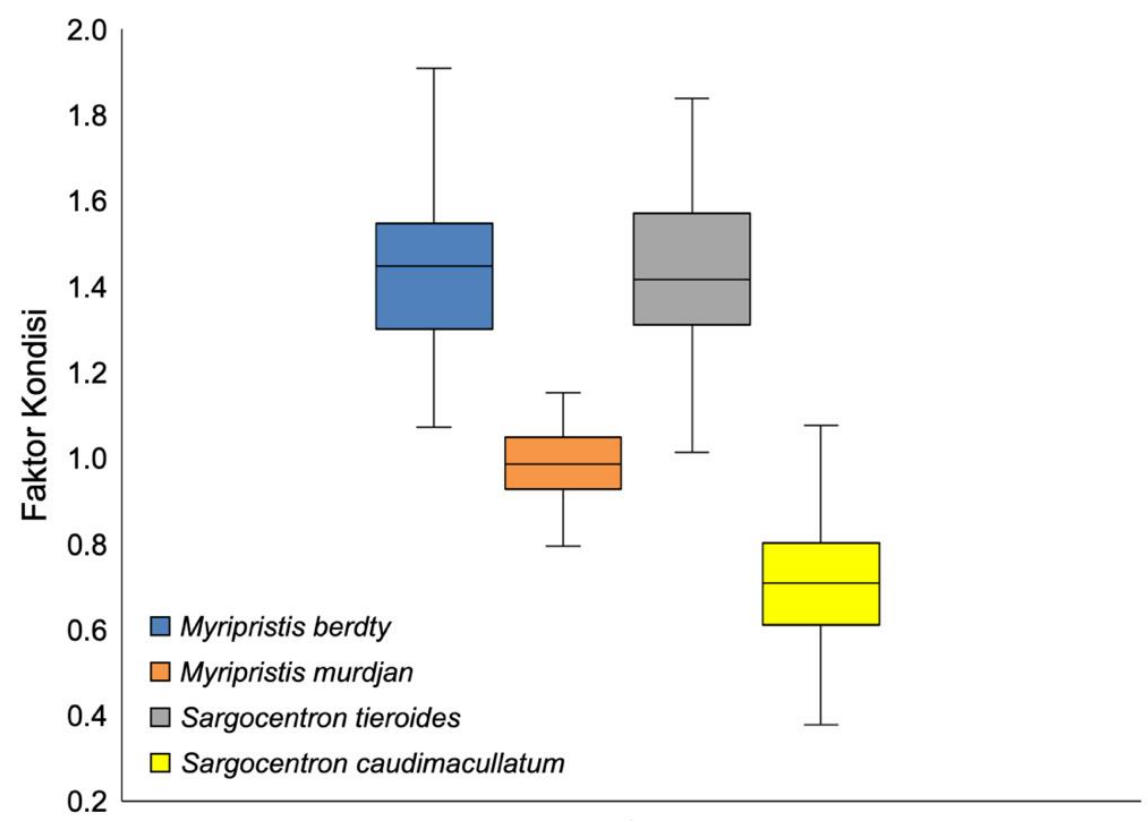

Gambar 7. Nilai faktor kondisi Myripristis berndty, Myripristis murdjan, Sargocentron tieroides dan Sargocentron caudimacullatum

perairan India (nilai $b=3.204$ ). Muchlisin et $a$. (2010) menyatakan bahwa ketersediaan makanan dan tingkah laku ikan merupakan faktor utama yang mempengaruhi tinggi rendahnya nilai b. Ikan yang kemampuan renangnya aktif menunjukkan nilai b yang lebih rendah bila dibandingkan dengan ikan yang kemampuan renangnya pasif. Hal ini berkaitan dengan banyaknya energi yang dikeluarkan untuk pergerakan dan pertumbuhan. Ikan yang berada pada arus tenang cenderung memiliki nilai b yang lebih tinggi dibandingkan ikan yang berada pada arus kuat.

Nilai faktor kondisi tertinggi diperoleh pada jenis Myripristis berndty $(k=1.417)$ dan terendah pada jenis sargocentron caudimacullatum ( $k=0,787)$. Nilai faktor kondisi Myripristis murdjan pada penelitian ini lebih rendah dibandingkan nilai faktor kondisi yang dilaporkan oleh Anbalagan et al. (2009). Anbalagan et al. (2009) melaporkan bahwa faktor kondisi Myripristis murdjan di Perairan India berkisar antara 2.0 - 3.90. Sementara itu, nilai faktor kondisi yang rendah juga dilaporkan ditemukan pada Sargocentron rubrum di wilayah perairan Mediterranean yaitu 0.23 - 0.54 (Golani dan Ben-Tuvia, 1985), sedangkan nilai nilai faktor kondisi >1 ditemukan pada Sargocentron rubrum dari wilayah perairan Medditeranean dan perairan India yaitu masing-masing berkisar antara 1.62-1.81 dan 1.15-1.20 (Farrag et al., 2018, Anbalagan et al., 2016).

Perbedaan nilai faktor kondisi ikan dapat dipengaruhi oleh habitat, jenis kelamin, tingkat kematangan gonad, dan beberapa faktor lainnya. Rodriguez et al. (2017) 
menjelaskan bahwa perbedaan faktor kondisi dapat disebabkan oleh perbedaan panjang, berat, musim dan habitat ikan. Adanya perbedaan nilai faktor kondisi antar jenis dalam satu genus yang sama diduga disebabkan oleh adanya perbedaan kebutuhan kondisi lingkungan, persaingan makanan dan musim pemjahan antar spesies. Selain itu, perbedaan musim pemijahan antar spesies dalam satu genus tentunya akan memberikan nilai faktor kondisi yang berbeda. Sebagai contoh, Sargocentron rubrum lebih menyukai perairan yang lebih dalam dan tidak terlalu terkait dengan habitat terumbu karang dibandingkan dengan spesies Holocentrinae lainnya (Golani dan Ben-Tuvia, 1985).

\section{KESIMPULAN}

Genus Myripristis memiliki karakter pembeda antar jenis yang lebih banyak (50.00\%) dibandingkan dengan genus Sargocentron (16.66\%). Myripristis berndty dan Myripristis murdjan memiliki lima karakter pembeda (SL,HL, CPL, HD, PFL dan VFL), sedangkan Sargocentron tieroides dan Sargocentron caudimacullatum hanya memiliki hanya karakter pembeda (SnL dan $\mathrm{PFL}$ ). Keempat jenis ikan yang diteliti dalam penelitian ini memiliki pola pertumbuhan alometrik negatif $(b<3)$. Genus Myripristis memiliki sebaran ukuran panjang total dan bobot total yang lebih rendah dibandingkan dengan genus Sargocentron. Nilai faktor kondisi tertinggi ditemukan pada Myripristis berndty, sedangkan nilai terendah teramati pada Sargocentron caudimacullatum. Penelitian lanjutan terkait variasi genus Myripristis dan Sargocentron yang hidup di perairan aceh masih diperlukan dalam rangka mendapatkan gambaran yang lebih komperhensif.

\section{DAFTAR PUSTAKA}

Allen, G.R., Steene, R., Humann, P. \& Deloach, N. 2003. Reef fish identification: tropical Pacific. New World Publications Incorporated.

Anbalagan, T., Murugan, A., Jawahar, P., Vijayanand, P., Saravanan, R. \& Veerappan, N. 2016. Age and growth of squirrel fish, Sargocentron rubrum,
(Forsskal, 1775) from Cuddalore waters, Southeast coast of India. Indian Journal of Geo-Marine Sciences, 45(12):1742-1748.

Anbalagan, T., Vijayanand, P. \& Veerappan, N. 2009. Length-Weight relationship and Condition Factor of Soldierfish Myripristis murdjan from Cuddalore Coast, South East Coast of India. Current Research Journal of Biological Sciences, 1 (1):18-20.

Artüz, M.L. \& Golani, D. 2018. First and most northern record of Sargocentron rubrum (Forsskål, 1775) from the Sea of Marmara. Thalassas: An International Journal of Marine Sciences, 34(2): 377-381. doi: 10.1007/s41208-018-0075-0

Bakhtiar, D., Djamali, A., Arifin, Z. \& Sarwono, T. 2012. Struktur Komunitas Ikan Karang di Perairan Pulau Tikus Kota Bengkulu. In Prosiding Seminar Nasional dan Rapat Tahunan Bidang IImU-IImu Pertanian BKSPTN Wilayah Barat Tahun.

De-Robertis, A. \& Williams, K. 2008. Weightlength relationships in fisheries studies: the standard allometric model should be applied with caution. Transactions of the American Fisheries Society, 137(3):707719. doi: 10.1577/T07-124.1

Edrus, I.N. \& Suharti, S.R. 2016. Sumber daya ikan karang di taman wisata alam Gili Matra, Lombok Barat. Jurnal Penelitian Perikanan Inclonesia, 22(4):225-242. doi: 10.15578/jppi.22.4.2016.225-242

Edrus, I.N., Wijaya, S.W. \& Setiawan, I.E. 2013. Struktur komunitas ikan karang di perairan Pulau Raya, Pulau Rusa, Pulau Rondo dan taman laut Rinoi dan Rubiah, Nanggroe Aceh Darussalam. Jurnal Penelitian Perikanan Inclonesia, 19(4):175-186. doi: 10.15578/jppi.19.4.2013.175-186

Effendie, M.I. 2002. Biologi Perikanan. Yayasan Pustaka Nusantara. Yogyakarta.

Effendie, M.I. 1979. Metoda Biologi Perikanan. Yayasan Dewi Sri. Bogor.

Fadhil, R., Muchlisin, Z.A. \& Sari, W. 2016. Hubungan Panjang-berat dan morfometrik ikan julung julung (Zenarchopterus dispar) dari perairan pantai utara Aceh. Jurnal IImiah Mahasiswa Kelautan Perikanan Unsyiah, 1(1):146-159.

Farrag, M.M., AbovelFadl, K.Y., Alabssawy, A.N., Toutou, M.M. \& El-Haweet, A.E.A. 2018. Fishery biology of lessepsian immigrant squirrelfishes Sargocentron 
rubrum (Forsskål, 1775), Eastern Mediterranean Sea, Egypt. The Egyptian Journal of Aquatic Research, 44(4):307313. doi: 10.1016/j.ejar.2018.10.003

Froese, R. 2012. Cube law, condition factor and weight-length relationships: history, meta-analysis and recommendations. Journal of Applied Ichthyology, 22(4):241253. doi: $10.1111 /$ j.1439-0426.2006.00805.x

Froese, R. \& Pauly, D. 2016. FishBase. World Wide Web electronic publication. www.fishbase.org.

García-Dávila, C.R., Magalhães, C. \& Guerrero, J.C.H. 2005. Morphometric variability in populations of Palaemonetes spp. (Crustacea, Decapoda, Palaemonidae) from the Peruvian and Brazilian Amazon Basin. Iheringia Série Zoologia, 95(3):327334. doi: 10.1590/S0073-47212005000300013

Golani, D. \& Ben-Tuvia, A. 1985. The biology of the Indo-Pacific squirrelfish, Sargocentron rubrum (Forsskal), a Suez Canal migrant to the Eastern Mediterranean. The Journal of Fish Biology, 27: 249-258. doi: 10.1111/j.10 95-8649.1985.tb04025.x

Haryono. 2001. Variasi Morfologi dan Morfometri lkan Dokun (Puntius lateristriga) di Sumatera. Biota, 6(3):109-116

Hedianto, D.A., Purnomo, K. \& Warsa, A., 2013. Interaksi pemanfaatan pakan alami oleh komunitas ikan di Waduk Penjalin, Jawa Tengah. Bawal, 5(1):33-40. doi: 10.15578 /bawal.5.1.2013.33-40

Jawad, L.A. 2015. Study of the vertebral column of the onion trevally, Carangoides caeruleopinnatus (Teleostei: Carangidae) collected from the Sea of Oman. Italian Journal of Zoology, 82(1):41-47. doi: 10.1080/11250003.2014.1000983

Kabakli, F. \& Ergüden, D. 2018. Length-Weight Relationship and Condition of Redcoat Sargocentron rubrum (Forsskål, 1775) in Iskenderun Bay (Southeastern Mediterranean, Turkey). Journal of Veterinary and Animal Sciences, 1 (3):23-26.

Krismono, A.S., Lathifa, A.R. \& Sukimin, S. 2017. Kebiasaan Makanan Ikan Motan (Thynnichthys polylepis) Di Waduk Koto Panjang Riau. Jurnal Iktiologi Indonesia, 8(1):25-34. doi: 10.32491/jii.v8il.284

Letourneur, Y., Kulbicki, M. \& Labrosse, P., 1998. Length-weight relationship of fishes from coral reefs and lagoons of $\mathrm{New}$
Caledonia: an update. Naga, the Iclarm Quarterly, 21 (4): 39-46.

Morato, T., Afonso, P., Lourinho, P., Barreiros, J. P., Santos, R. S. \& Nash, R. D. M., 2001. Length-weight relationships for 21 coastal fish species of the Azores, north-eastern Atlantic. Fisheries Research, 50(3): 297302. doi: 10.1016/S0165-7836(00)00215-0

Maghfiriadi, F., Zulfahmi, I., Paujiah, E. \& Sarong, M.A. 2019. Ichthyofauna of Alas River, around Soraya Research Station, Leuser Ecosystem Area, Subulussalam, Aceh. Jurnal Iktiologi Indonesia, 19(3): 361-374.

Muchlisin, Z.A., 2013. Morphometric variations of Rasbora group (Pisces: Cyprinidae) in lake Laut Tawar, Aceh province, Indonesia, based on Truss character analysis. Hayati : Journal of Biosciences, 20(3):138-143. doi: 10.4308/hjb.20.3.138

Muliati, Yasidi, F. \& Arami, H. 2017. Studi kebiasaan makanan Ikan Baronang (Siganus canaliculatus) di perairan Tondonggeu Kecamatan Abeli Sulawesi Tenggara. Jurnal Manajemen Sumber Daya Perairan, 2(4):287-294.

Nair, R.J. \& Dineshkumar, S. 2016. New distributional records of three soldier fishes (Pisces: Holocentridae: Myripristis) from Indian waters. Marine Biodiversity Records, 9(1):1-15. doi: 10.1 186/s41200-016-0092-8

Özvarol, Y. \& Tatlises, A., 2017. Some biological aspects of lessepsian Sargocentron rubrum (Forsskål, 1775) in the North Cyprus, Mediterranean Sea. Scientific Papers: Series D, Animal Science-The International Session of Scientific Communications of the Faculty of Animal Science.

Putri, M.R.A. \& Sulaiman P.S. 016. Status Kondisi Kualitas Perairan Teluk Cempi. Model Konservasi Ekosistem untuk Pemulihan dan Keberlanjutan Potensi Sumber Daya Ikan Teluk Cempi, Nusa Tenggara Barat.

Ramses, R., Ramli, A., Agustina, F. \& Syamsi, F., 2020. Hubungan Panjang-Berat, dan Faktor Kondisi Ikan Belanak (Mugilidae) di Perairan Pulau Panjang, Kota Batam. Jurnal Penelitian Sains, 22(3):133-143. doi: 10.26554/jps.v22i3.579

Rodríguez-Mendoza, R., Munoz, M. \& Saborido Rey, F. 2011 . Ontogenetic allometry of the bluemouth, Helicolenus dactylopterus dactylopterus (Teleostei: Scorpaenidae), 
in the Northeast Atlantic and Mediterranean based on geometric morphometrics. Hydrobiologia, 670(1):522. doi: 10.1007/s10750-011-0675-7

Rodriguez, C., Galli, O., Olsson, D., Tellechea, J.S. \& Norbis, W. 2017. Length-weight relationships and condition factor of eight fish species inhabiting the Rocha Lagoon, Uruguay. Brazilian Journal of Oceanography, 65(1):97-100. doi: 10.1590/s1679-8759 2017107306501

Rudi, E., Iskandar, T., Fadli, N. \& Hidayati, H., 2012. Impact of mass coral bleaching on reef fish community and fishermen catches at Sabang, Aceh Province, Indonesia. Aquaculture, Aquarium, Conservation \& Legislation, 5(5):309-320.

Rypel, A.L. \& Richter, T.J. 2008. Empirical percentile standard weight equation for the blacktail redhorse. North American Journal of Fisheries Management, 28(6): 1843-1846. doi: 10.1577/M07-193.1.

Schindler, I. \& Schmidt, J. 2006. Review of the mouthbrooding Betta (Teleostei, Osphronemidae) from Thailand, with descriptions of two new species. Zeitschrift für Fischkunde, 8(1/2):47-69.

Streissl, F. \& Hödl, W., 2002. Growth, morphometrics, size at maturity, sexual dimorphism and condition index of Austropotamobius torrentium Schrank.
Hydrobiologia, 477(1-3):201-208. doi: 10.10 23/A:1021046426577

Sukmono, T., Duryadi, D., Rahardjo, M.F. \& Affandi, R. 2013. Keanekaragaman ikan di Harapan Rainforest Jambi: Eksplorasi Pendahuluan. In Simanjuntak C, Rahardjo MF, Zahid A, Hadie W, Haryono (editor). Keanekaragaman ikan: Konservasi dan pengelolaan bagi kesejahteraan masyarakat pesisir. Prosiding Seminar Nasional Ikan VII. Masyarakat Iktiologi Indonesia. Bogor, 12 Juni.

Sumadhiharga, O.K., Djamali, A. \& Badrudin, M. 2006. Keanekaragaman Jenis Ikan Karang di Perairan Belitung Barat, Kepulauan Bangka Belitung. IImu Kelautan: Indonesian Journal of Marine Science, 11(4): 201-209.

Taskavak, E. \& Bilecenoglu, M. 2001. Lengthweight relationships for 18 Lessepsian (Red Sea) immigrant fish species from the eastern Mediterranean coast of Turkey. J. Mar. Biol. Assoc. U.K., 81(5): 895. doi: $10.1017 /$ S0025315401004805

Violle, C., Reich, P.B., Pacala, S.W., Enquist, B.J. \& Kattge, J. 2014. The emergence and promise of functional biogeography. Proceedings of the National Academy of Sciences, 111 (38):13690-13696. doi: 10.107 3/pnas.1415442111

Walpole, R.E. 1995. Pengantar statistic. PT. Gramedia Pustaka Utama, Jakarta. 